\title{
The Fate of Ovarian Tissues when planted on different Organs.
}

\author{
By \\ Charles R. Stockard, \\ Cornell Medical School, New York City, U.S.A. \\ With 2 figures in text and Plates $\mathrm{XI}-\mathrm{XIII}$. \\ Eingegangen am 20. Januar 1911.
}

It is a well known fact as has been shown in the case of the ovary and thyreoid that an entire organ may be transplanted from one individual to another without discontinuing to grow or function. GUTHRIE and CASTLE have found that fowls and guinea pigs with transplanted ovaries may ovulate and reproduce in an entirely normal manner. MeIsenheimer has condueted a most elaborate and beautiful series of experiments to show that although the sex glands may easily be transplanted from one to the other sex in caterpillars yet the moths into which these caterpillars metamorphose show the typical secondary sexual characters of their original sex, not being affected by secretions from the transplanted bodies. All of these experiments indicate that there is no antagonistic action towards the organs of a different individual, even of the opposite sex, when planted into the body of another individual of the same species of animal.

Yet we seem to face a different proposition when considering the transplantation of portions of organs or tissues from one animal to another. In most cases such pieces of organs or tissues live and may actually grow for a time but invariably they cease to grow and finally disappear entirely. In this way normal tissues differ from malignant growths which continue to grow sometimes even more actively after transplantation. 
It is also true, and I think a point of importance, that the ability of a tissue transplant to live and grow depends largely upon the kind of tissue on which it is planted. The indiscriminate injections of tissue emulsions and tissue pulps of both adult and embryonic tissue as sometimes used in the experimental study of cancer, are most unreliable and rarely give results owing to the hit and miss method employed. All tissue transplants must be carefully made and a circulation established by grafting in minute blood vessels, before deductions are to be drawn from the reactions which follow. It is evident that if the transplant is not properly nourished during the first hours or days it will begin to undergo degenerative changes which will in all cases effect its future behavior.

With these points in view the questions arise: First, do certain transplanted tissues survive equally well when planted on any organ, or do they survive longer and better on certain organs than on others (provided of course that the attachment and circulation is equally good in all cases)? Secondly, if they do survive better on certain organs what relationship exists between the tissues and these organs and what is the cause of their better survival?

Leo LOEB and ADDison showed a few years ago that when guinea pig tissue was planted into other species of animals and into other guinea pigs, that the tissue always grew better in guinea pigs than in any other animal; and it was further indicated that the tissue survived for a shorter time the more distantly related was the species into which it was transplanted. Thus, as might have been expected there is a specific reaction on the part of the body of an animal to the transplanted tissues of other species of animals.

The present experiments, although of a preliminary nature, bear upon the question of a resistance or antagonism between the tissues of one organ and those of another in either the same individual or other individuals of the same species. And also the further question, of antagonism between different tissues, or different cells, in similar organs.

The animals used in these experiments were guinea pigs and the common salamander Diemyctylus viridescens. The tissue chosen for transplantation was that of the ovary since it is composed of two so entirely different classes of cells, the stroma tissue and the germ cells or ova, and further as an organ is so interestingly related to the testis of the male. Pieces of the ovary of guinea pigs were 
transplanted into the testis and into the body wall and liver tusses of the male. They lived better when planted into the testicle and here the artificially established circulation seemed more efficient than in other organs. Nevertheless, all of the experiments with ten guinea pigs were unsatisfactory since in no cases did the transplanted tissue live sufficiently long or well to allow valid comparisons. Ribbert, Lubarsch, Levin, Loeb and others have all had similar experiences in transplanting the tissues of mammals. The tissues may grow for a short while but soon stop and ultimately all disappear. Inflamatory conditions are also commonly produced in the guinea pigs if not operated upon with great care.

With the salamanders the experiments were much more satisfactory, the ovarian tissue is easily transplanted and grows and lives for several months, in many of the cases, and undergoes changes so slowly and uniformly as to permit careful study and comparisons.

Thirty individuals were employed in the experiments and portions of ovary in various degrees of maturity were planted on the liver, lungs, kidney, stomach and body wall of the same individual and on the testis, stomach, kidney, body wall, lungs and liver of male salamanders. The ovarian tissue grew equally well on similar organs of the male as upon those of the female, showing that there is no marked individual reaction against the tissues of other specimens, even though of the opposite sex. The most favorable of all transplants, as will be considered below, was that of ovary tissue on the testis.

The transplanted tissue in all cases was carefully attached to the new organ with the finest silk or gut fibre suture and neighboring blood ressels were dissected out and embedded within and around the tissue, the entire operation being performed under the binocular microscope. The blood vessels in almost every case readily sent out branches and supplied the new tissue.

\section{Ovarian tissue on the testis.}

The tissue from the ovary, as stated above, was most persistant and successful in its growth when planted upon the testis. A portion of the ovary containing ova or germinal epithelium and stroma tissue was planted in a pocket or slit cut in the testis, a branch of the spermatic artery was carefully dissected loose and placed around the ovarian mass which was fastened to the testicle by a silk or 
gut-fibre suture. Ten such operations were entirely successful. The ovarian piece was well nourished and the ova continued to grow, in most cases each ovum having a plexus of capillaries about it as is shown in the camera drawings (Figs. 1 and 2).

After forty-one days the entire plant is in an apparently normal condition (Figs. 1 and 2). There are no indications of degeneration in either the egg cells or stroma (PI. XI, Fig. 1). At no time does there seem to be a tendency for the cells of the testicular stroma to migrate in, or replace the ovarian stroma cells. The separation between the Fig. 1.

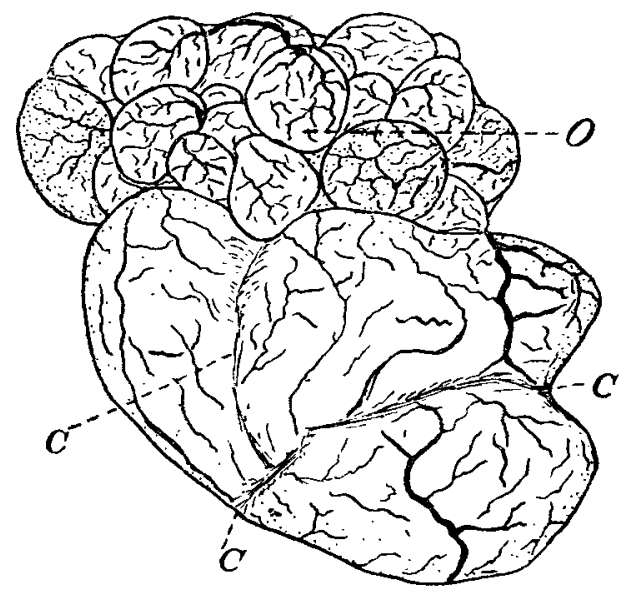

A camera drawing showing part of an ovary planted on the testis of a salamander 41 days after the operation. 0 Ora, all well supplied by capillaries indicated in black lines; $C^{\prime}$ scars resulting from the cuts made during the operation.

testicular and ovarian tissue remains distinct. As will be mentioned

Fig. 2.

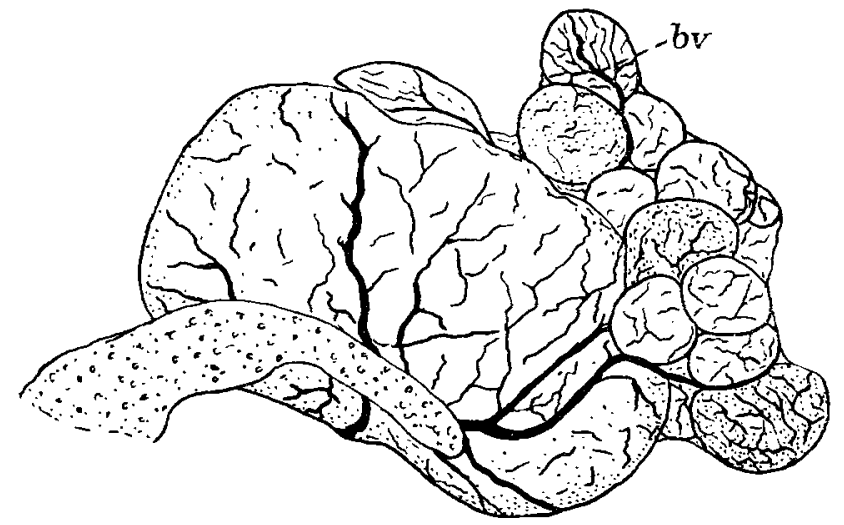

The same specimen shown from the opposite side. The heary lines indicate the rich supply of blood vessels, $b v$.

below, this is in contrast to the reaction of other tissues to the ovarian transplant (see Figs. 2 and 4, Plates XI and XII).

The egg cells seem to be unable to continue their growth as 
they are highly laden with yolk and need certain conditions for their maturation and further multiplication or development. The yolk granules then begin to loosen apart, and later globules are formed by the fusion of groups of granules; these globules become scattered throughout the ovarian tissue as is seen by comparing transplants of different ages (Plate XII, Figs. 3 and 4, and Plate XIII, Figs. 6 and 7). These globules persist for as long as seven months and might for much longer. It thus seems that the stroma cells do not tend to appropriate yolk bodies as food. This inability of these cells to use yolk as food, or to absorb it, is necessary that the egg cells may have an opportunity to accumulate or form yolk in the presence of the stroma tissue. Yolk granules disappear much earlier in ovarian transplants on other organs since the cells of these organs migrate into the ovarian piece and dissolve or absorb the yolk grains.

After the dissipation of the yolk, as for example, in a seven months' transplant (Plate XIII, Figs. 6 and 7) the ova cells can no longer be distinguished, the entire piece seems of the stroma cell type with yolk globules scattered through the tissue. In rare cases, however, masses of yolk globules are localized and probably represent the persistant remains of an egg cell (Plate XII, Fig. 3). The pigment granules of the egg are lost and cannot be identified in the old plants.

The ovarian stroma persists and is well preserved in the transplants of seven months' duration. They would doubtless have lasted much longer if specimens could have been kept after this time.

It appears then, that there is little antagonistic response between two such organs as the ovary and testis and that the tissues of these organs do not tend to replace or destroy one another, thus they may live and grow side by side. The ova persist perfectly for one or two months and then undergo retrogressive changes probably on account of having passed the period at which they should have matured or undergone some important modification. The stroma of the ovary, however, is not attacked by the testicular stroma and may survive in an apparently perfect condition for longer than seven months, which is as far as the observations extended. Ovarian transplants on all other organs had entirely disappeared long before, neither the ova or stroma being able to exist in contact with the tissue cells of such organs. 


\section{Ovarian tissue on the liver.}

Ovarian tissue when planted on the liver with a blood supply established persists longer than on any other organ except as discussed above on the testis. The ovarian tissue persists equally well on the liver of the same individual or on that of a male of the same species of salamander. In no case out of fifteen successful transplants on the liver did the blood vessels branch and supply the ovarian piece so efficiently as did the branches of the spermatic artery. This was due to the fact that no artery of the liver could be so nicely placed about the piece as could the spermatic of the testis. The circulation of the liver-plant, however, was very good and easily sufficient to have supplied the piece as was shown by the length of time it persisted. The difference in circulation does not account for the earlier fate of the ovarian piece on the liver, but this difference was due to the different way in which the liver tissue or cells themselves reacted to the strange tissue. While there was no tendency on the part of the testicular stroma to encroach upon the ovarian tissue and replace its cells by wandering testicular cells, the liver very soon reacted in such a manner.

The ova and stroma cells lived well on the liver for several weeks though they did not grow very much. After this time, however, the cells of the liver had encroached and migrated into the ovarian tissue apparently replacing and destroying the tissue before it. The ovarian piece decreases in size and the ova gradually loose their yolk and finally themselves disappear. Fig. 2, Plate XI and Fig. 4, Plate XII show an ovarian piece planted upon the liver; it will be noticed that the liver tissue extends into the ovarian part and many liver cells have migrated far into the transplant, the typical pigment spots of the liver are seen in the ovarian graft in Fig. 4, Plate XII. These figures are photographs of a 42 day transplant and may be compared with Fig. 1 Plate XI which is a transplant of about equal duration on the testis.

Transplanted on the liver the ova show all indications of degeneration and breaking down while on the testis they are in a normal healthy condition. The large blood vessel, $b v$, at the base of the transplant on the liver as well as smaller vessels shown in the sections of the transplanted tissue would indicate that the piece was sufficiently nourished and did not degenerate on account of a poor blood supply. 
The liver cells, then, show a kind of antagonistic action against the ovarian tissue which is not shown by the cells of the testis. This we may speak of as the antagonism between two different organs or the antagonism between tissues of different organs. A more pronounced antagonism, mentioned before as shown by LEO LOEB for transplanted tissues and well known from many haemolysis experiments, is that which exists between the tissnes or parts of animals of different species, specific antagonism.

\section{Ovarian tissue on lung, kidney, stomach and body wall.}

Pieces of ovary planted upon the lungs, kidney, stomach or body wall of the same or of another individual often live for a short time before being absorbed but usually disappear within a week or ten days after the experiment, only three out of more than fifty such transplants lived as long as 45 days. These three were almost completely replaced and would have soon disappeared.

A fair circulation may be established for the transplant on any of these organs, yet the ovarian tissues seem unable to maintain themselves in such an environment and both ova and stroma begin to degenerate and are readily replaced or absorbed by the cells and tissues of the supporting organ.

It is difficult, from the observations at hand, to state whether or not certain of these organs are more antagonistic to ovarian tissue than others. The wall of the stomach is an unfavorable place to make a transplant, but the body wall would seem favorable since a good circulation is easily obtained, yet the tissue readily breaks down and disappears in either place. Transplants on or within the delicate lung tissue often break away but do not thrive even when successfully made, and pieces of ovary on the kidneys readily disappear.

\section{Summary and Conclusions.}

From these experiments on thirty salamanders it would seem that the behavior or fate of transplanted tissues depends largely upon the nature of the organ upon which the tissue is transplanted. Ovarian tissue grows and lives incomparably better when transplanted upon the testis than upon any other of the body organs experimented upon.

The next most favorable ground for this tissue was upon the liver, although here the liver cells soon begin to encroach upon the 
ovarian mass replacing and absorbing its cells. On other organs the ovarian tissue undergoes degeneration and absorption within a very limited time.

Ovarian tissue planted upon the testis persisted with the stroma in good condition for more than seven months. On the liver ovarian tissue was found still to contain ova and stroma after more than 45 days. While on the body wall, lungs, kidney and wall of the stomach the tissue disappears within about two weeks, only three indications, in more than fifty such transplants, were found after 45 days and these had almost disappeared.

It is very important, therefore, to realize that there is a marked difference between the reactions of certain tissues to others, and all transplants should be made in the most careful manner between organs of as near as possible a similar type. The introduction of mixtures or emulsions of adult or embryonic tissue into different parts of the body is a very unreliable method and one likely to give most contradictory results, depending upon the proportion of certain tissues present which successfully plant, and upon the organ of the host into which the tissues are placed or happen to reach.

Just as there is a specific reaction between the tissues of animals of different species which tends to prevent the growth of foreign tissue when planted in their bodies, there seems to be, from this preliminary series of experiments, a reaction between the tissues of different organs of the same or different individuals which causes transplanted tissue to exist to better advantage on one, usually a more closely similar organ, than on another.

\section{Zusammenfassung und Schlußfolgerungen.}

Nach den vorstehenden Versuchen an 30 Salamandern hängt das Verhalten oder das Schicksal transplantierter Gewebe anscheinend weitgehend von der Natur des Organs ab, auf welches sie transplantiert wurden. Ovarialgewebe wächst und lebt bei Transplantation anf den Hoden unvergleichlich viel besser, als auf irgend einem andern der in den Versuchen gewählten Körperorgane.

Den nächstgünstigsten Grund für dieses Gewebe stellte die Leber dar, obgleich hier schon die Leberzellen anf die Ovarialmasse iiberzugreifen und deren Zellen zu ersetzen und zu absorbieren anfangen. Auf andern Organen unterliegt das Ovarialgewebe bereits innerhalb einer sehr beschränkten Zeit der Entartung and Absorption.

Auf den Hoden überpflanztes Ovarialgewebe erhielt sich mit dem Stroma mehr als 7 Monate lang in guter Verfassung. Auf der Leber fand sich Eierstockgewebe noch nach mehr als 45 Tagen im Besitz von Eiern und Stroma. 
Während auf der Körperwand, den Langen, den Nieren und der Bauchwand das Gewebe ungefähr im Laufe zweier Wochen zu verschwinden pflegt, fanden sich im ganzen zweimal Anzeichen desselben, unter mehr als 50 derartigen Transplantationen, nach 45 Tagen, und anch diese bereits im Verschwinden begriffen.

Es ist daher sehr wichtig, festzustellen, daß hier ausgeprägte Unterschiede in den Reaktionen gewisser Gewebe auf andre bestehen, und alle Transplantationen sollten daher so sorgfältig als möglich zwischen Organen von möglichst nahestehendem Typus vorgenommen werden. Die Einführung erwachsener oder embryonaler Gewebe in Gestalt von Mixturen und Emulsionen in verschiedene Teile des Körpers ist eine sehr unzuverlïssige Methode, geeignet, zu ganz widersprechenden Ergebnissen za führen und abhängig von dem Vorbandensein eines entsprechenden Betrages erfolgreich überpflanzbarer Gewebe, endlich von dem Organe des Wirts, in welches die Einpflanzung stattfindet, oder welches sie zufällig erreichen.

Gerade so, wie es eine spezifische Reaktion zwischen den Geweben verschiedenartiger Tiere gibt, welche das Wachstum eingepflanzten fremdartigen Gewebes zu verhindern strebt, so scheint nach dieser vorläufigen Versuchsreihe auch zwischen den Geweben verschiedenartiger Organe desselben oder verschiedener Individuen eine Reaktion zu bestehen, welche einem transplantierten Gewebe vorteilhaftere Existenzbedingungen auf einem, gewöhnlich einem näher verwandten, Organ verschafft, als auf einem andern.

(Übersetzt von W. Gebhardt, d. 6. II. 1911.)

\section{Literature cited.}

Castle, W. E., On the Nature of Mendelian Factors. Read before Am. Soc. of Naturalists. 1909.

GUTHRre, C. C., Further Results of Transplantation of Ovaries in Chickens. Journ. Exp. Zool. V. 1908.

Levin, I., Cell Proliferation under Pathological Conditions with especial Reference to the Etiology of Tumors. Journ. Med. Research. VI. 1901.

Loeb, L., und AdDison, W. H. F., Beiträge zur Analyse des Gewebewachstums. II. Transplantation der Haut des Meerschweinchens in Tiere verschiedener Species. Archiv f. Entw.-Mech. XXVII. 1909.

Meisenheimer, J., Experimentelle Studien zur Soma- und Geschlechtsdifferenzierung. Erster Beitrag. Jena, Fischer, 1909.

Rous, P., Comparison of Conditions that Regulate the Growth of Transplanted Tumor and Transplanted Embryo. Jonrn. Am. Med. Assoc. LIV. 1910.

\section{Explanation of Plates.}

All figures are microphotographs of sections through transplants of ovarian tissue of various ages upon the testis and liver of the male salamander, Diemyctylus viridescens.

\section{Plate XI.}

Fig. 1. A 41 days old ovarian graft upon the epididymal end of the testis. The ova and ovarian stroma are still in normal condition. Ov ovary, Ep Epididymis. 

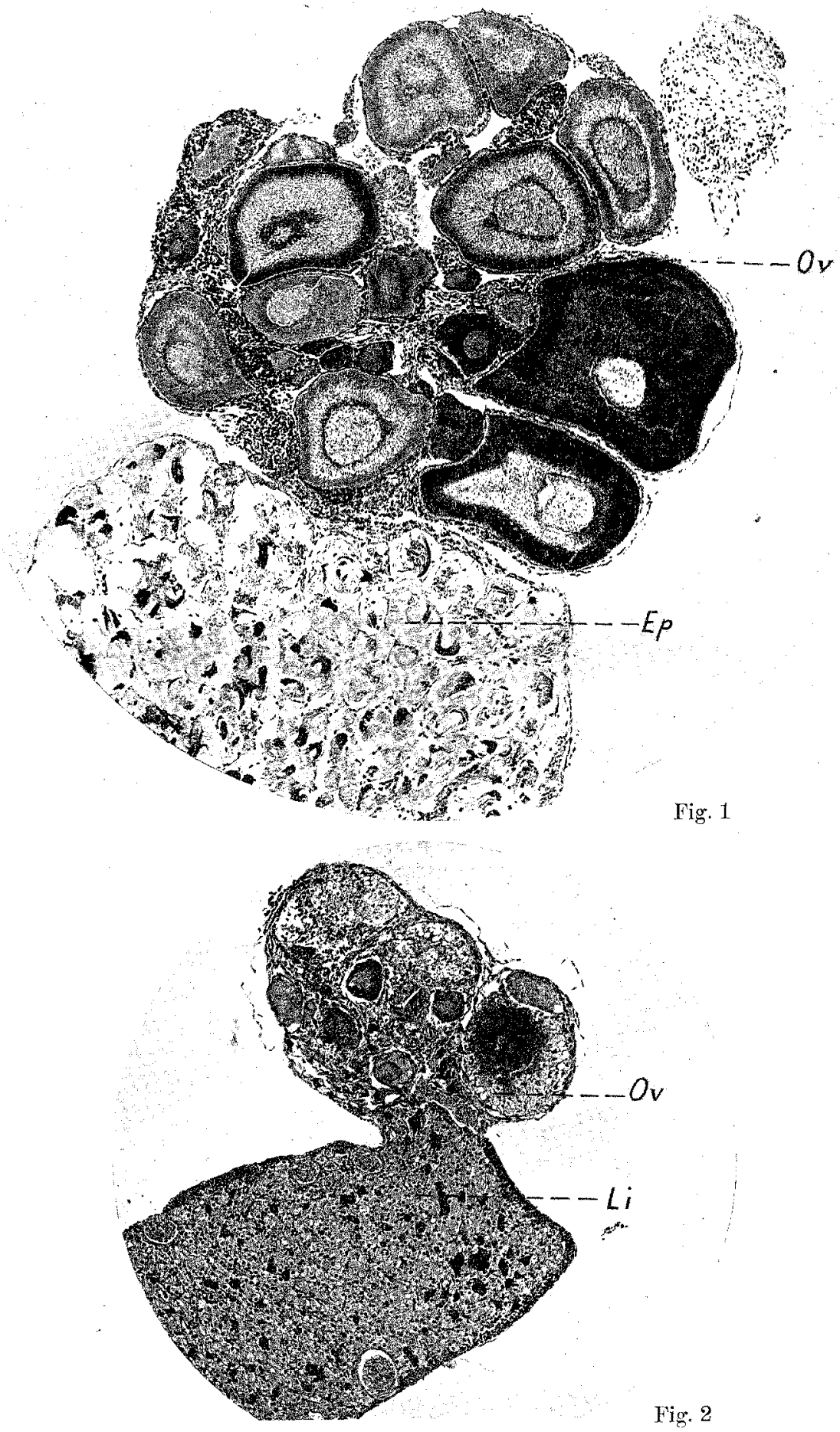

Fig. 2 

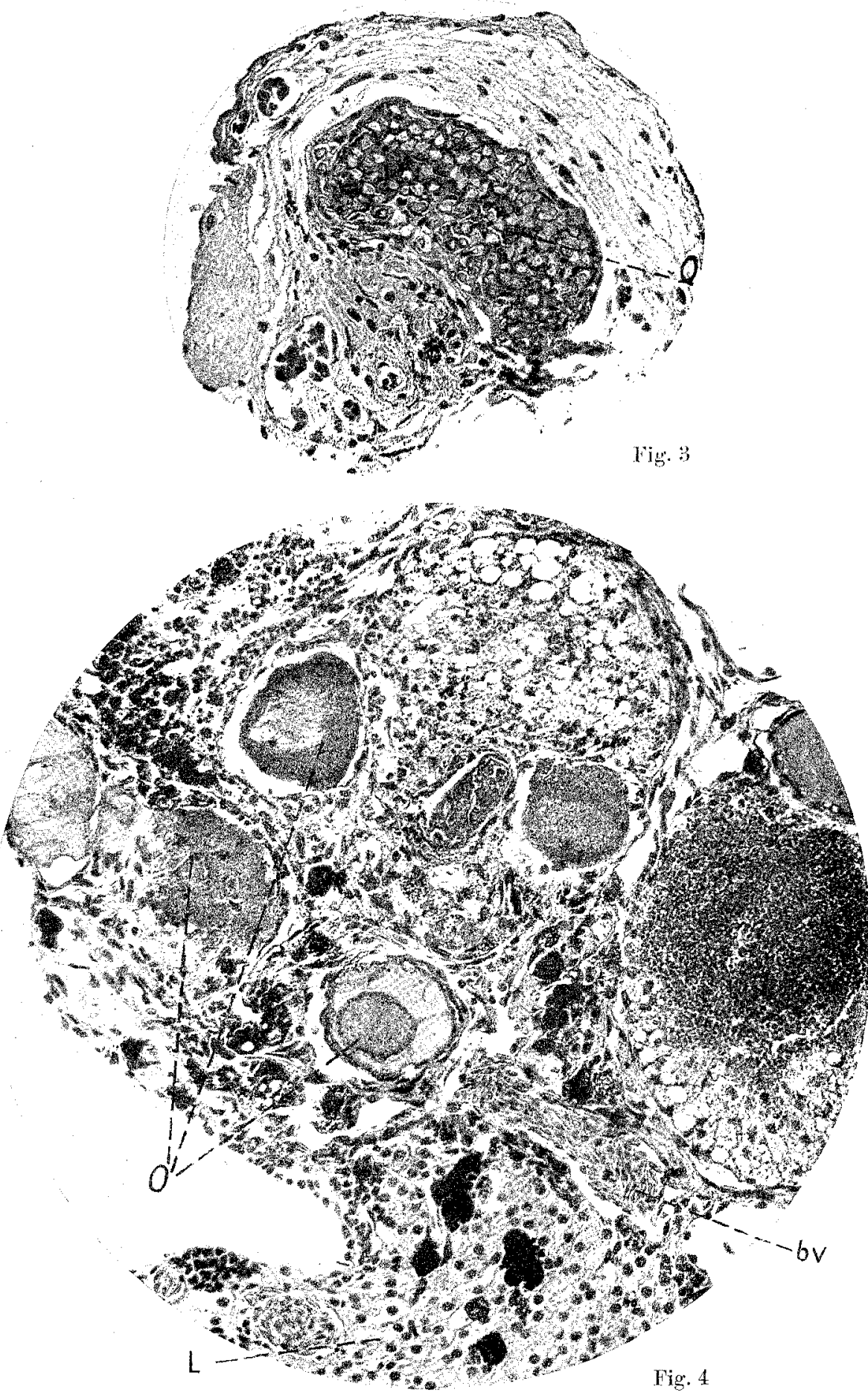


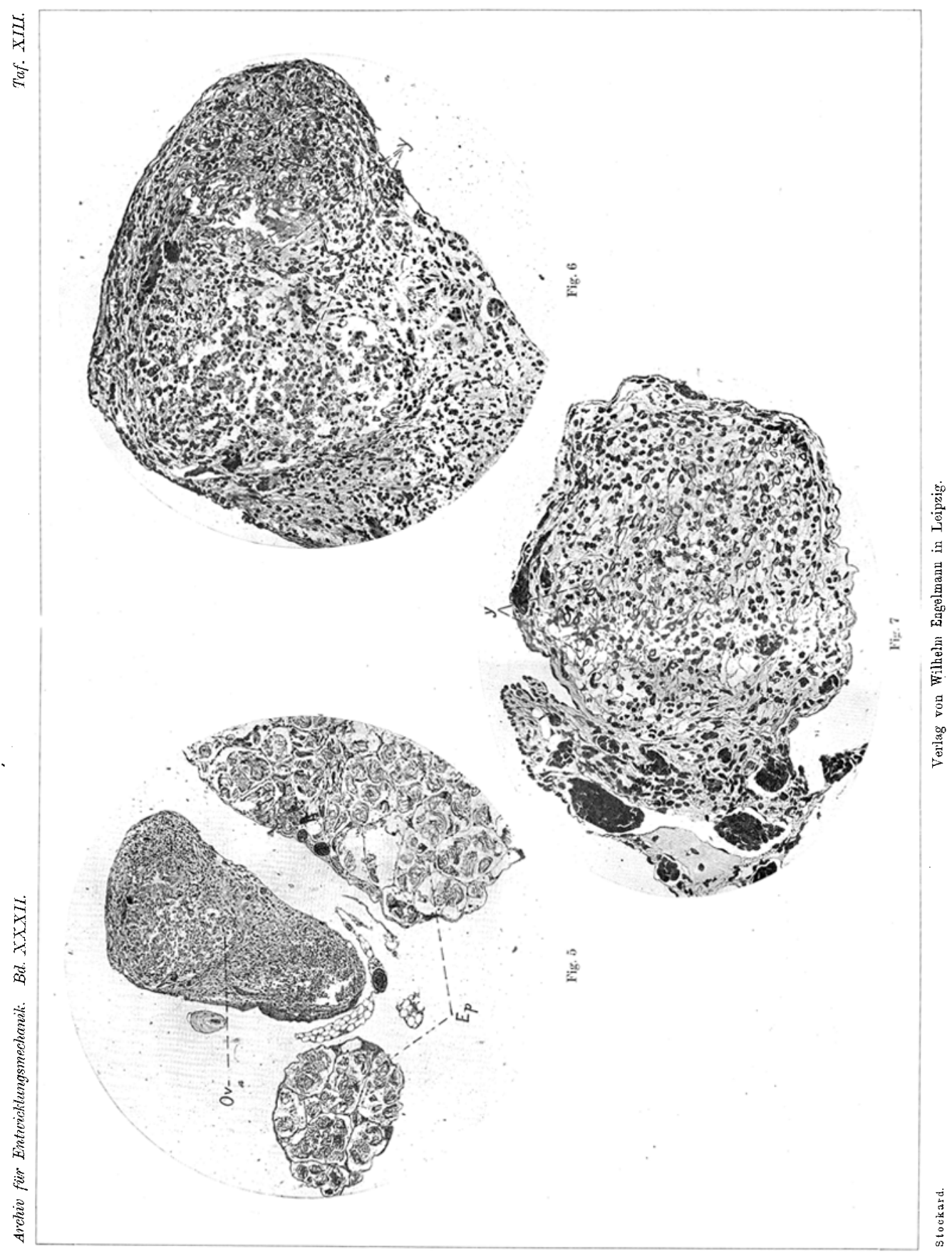


Fig. 2. An ovarian mass of about the same age planted on the liver. The two sections are equally magnified and it is noted that the ovarian parts planted on the liver are much reduced the ova being very small and almost all of the yolk of the egg cells has been lost. Ov ovary, Li liver.

\section{Plate XII.}

Fig. 3. A highly magnified section of ovarian tissue after seven months existance on the testis. An ovum, $O$, is shown in which the yolk granules have massed into globules.

Fig. 4. A higher magnification of the portion of ovary shown in Fig. 2 plate XI which has been planted upon the liver of a male for 42 days. The liver cells and liver pigment are shown to be encroaching upon the ovarian mass. $O$ ova, $b v$ large blood vessel at the base of the transplanted tissue. Compare the ova, $O$, with that of the seven month transplant in Fig. 3.

\section{Plate XIII.}

Fig. 5. A portion of ovary, $o v$, that has been living for seven months npon the testis, Ep. All of the ova have disappeared but the stroma is still in good condition.

Fig. 6. A higher magnification of the section of ovary in Fig. 5. Scattered throughout the stroma are seen yolk globules, $y$, which represent the remains of the once large egg cells.

Fig. 7. A highly magnified section from another specimen of ovary after seven months upon a testis. Here also the yolk globules, $y$, are scattered through the stroma. 